Short Note

\title{
Methyl 3,4-Dicarboxy-3-hydroxyeicosanoate
}

\author{
Yoshihito Shiono *, Tetsuya Murayama and Takuya Koseki \\ Department of Food, Life, and Environmental Science, Faculty of Agriculture, Yamagata University, \\ Tsuruoka, Yamagata 997-8555, Japan; E-Mails: mtetsuya@tds1.tr.yamagata-u.ac.jp (T.M.); \\ tkoseki@tds1.tr.yamagata-u.ac.jp (T.K.)
}

* Author to whom correspondence should be addressed; E-Mail: yshiono@tds1.tr.yamagata-u.ac.jp; Tel. +81-235-28-2873; Fax +81-235-28-2820.

Academic Editor: Norbert Haider

Received: 19 March 2015 / Accepted: 26 May 2015 / Published: 29 May 2015

\begin{abstract}
Methyl 3,4-dicarboxy-3-hydroxyeicosanoate (1) was isolated from the acetone extract of the fruiting bodies of Ciborinia camelliae Kohn. The planar structure of $\mathbf{1}$ was elucidated by spectroscopic methods.
\end{abstract}

Keywords: Ciborinia camelliae; camellia flower blight; agaricic acid

\section{Introduction}

Camellia flower blight, one of the most serious diseases of Camellia spp., is caused by the fungus Ciborinia camelliae Kohn [1]. Generally, this disease is most frequently observed in early spring. At first, ascospores released from apothecia, saucer-shaped fruiting bodies, of $C$. camelliae adhere to the surface of camellia petals and rapidly infect the flowers, causing the development of many small brown spots. Then, the infected flowers turn brown and fall to the ground prematurely. The fungus forms sclerotia in the fallen flowers and remains throughout winter until the next season. In spring, apothecia that are produced from the sclerotia release the ascospores, which are then spread through air. An apothecium, measuring $1 \mathrm{~cm}$ in diameter, has a slender stipe up to ca. $1-5 \mathrm{~cm}$ long. This is the characteristic cycle of $C$. camelliae Kohn. In a previous phytochemical investigation, a lectin was isolated from apothecia of $C$. camelliae Kohn [2]. However, very little is known about the secondary metabolites related to host/parasite relationships [1,3]. In our research on the chemical constituents of apothecia of $C$. camelliae Kohn, we isolated $\mathbf{1}$ from an acetone extract of this fungus. As a dicarboxylic acid with hexadecyl alkyl side chain, agaricic acid has been reported [4]. Agaricic acid 
has been isolated from fungi including basidiomycetes, Polyporus officinalis, and P. igniarius, and it can participate in the transport of adenosine diphosphate (ADP) and adenosine triphosphate (ATP) and function as an inducer of mitochondrial permeability transition [5]. Here, we describe the isolation and structure elucidation of $\mathbf{1}$ (Figure 1).

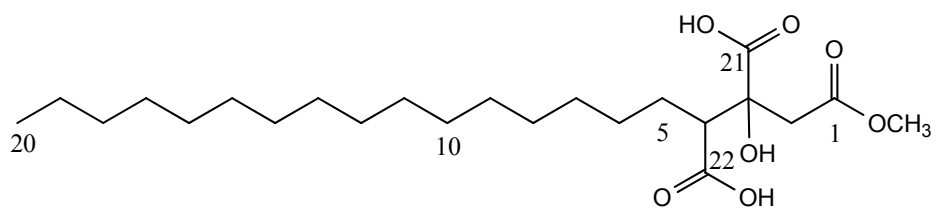

Figure 1. Structure of 1.

\section{Results and Discussion}

High resolution electrospray ionization time-of-flight mass spectrometry (HRESITOFMS) and NMR data showed that $\mathbf{1}$ has the molecular formula $\mathrm{C}_{23} \mathrm{H}_{42} \mathrm{O}_{7}$, implying that $\mathbf{1}$ has three degrees of unsaturation. The ${ }^{13} \mathrm{C}$ NMR (Table 1) and DEPT spectra of 1 revealed the presence of 16 signals for 23 carbons that included one methyl, one methoxy, 16 methylene, one methine, one quaternary, and three carbonyl carbons. The IR spectrum showed the absorption band characteristic of hydroxyl $\left(3463 \mathrm{~cm}^{-1}\right)$ and carbonyl (1737 and $1698 \mathrm{~cm}^{-1}$ ) groups. ${ }^{13} \mathrm{C}$ NMR $\left(\delta_{\mathrm{C}} 172.3,176.2,176.4\right)$ of 1 and formation of trimethyl esters via treatment with trimethylsilyldiazomethane supported the presence of two carboxyl groups. The ${ }^{1} \mathrm{H}$ NMR spectrum (Table 1$)$ of 1 showed a methoxy proton $\left[\delta_{\mathrm{H}} 3.64(3 \mathrm{H}, \mathrm{s})\right]$, long-chain alkyl protons $\left[\delta_{\mathrm{H}} 0.90(3 \mathrm{H}, \mathrm{t}, J=7.4 \mathrm{~Hz}, \mathrm{H} 3-20), 1.26-1.28\right.$ (approximately $\left.\left.28 \mathrm{H}, \mathrm{m}\right)\right]$, isolated methylene protons $\left[\delta_{\mathrm{H}} 2.72(1 \mathrm{H}, \mathrm{d}, J=15.9 \mathrm{~Hz}, \mathrm{H}-2), 3.10(1 \mathrm{H}, \mathrm{d}, J=15.9 \mathrm{~Hz}, \mathrm{H}-2)\right]$, and a methine proton $\left[\delta_{\mathrm{H}} 2.65(1 \mathrm{H}, \mathrm{dd}, J=9.0,2.5 \mathrm{~Hz}, \mathrm{H}-4)\right]$. The structure of 1 was elucidated based on the results of ${ }^{1} \mathrm{H}-{ }^{1} \mathrm{H}$ COSY (correlation spectroscopy), ${ }^{13} \mathrm{C}-{ }^{1} \mathrm{H}$ COSY, and HMBC experiments. In the HMBC analysis (Figure 2), the correlations from $\mathrm{H}-2$ to $\mathrm{C}-1, \mathrm{C}-3$, and $\mathrm{C}-21$, from $\mathrm{H}-4$ to $\mathrm{C}-21$, and from $\mathrm{H}-5$ to $\mathrm{C}-22$ indicated the structure of a 3,4-dicarboxy-3-hydroxymethyl butanoate moiety substituted by the alkyl moiety. From the above data, the structure of $\mathbf{1}$ was determined as shown in Figure 1. To our knowledge, this represents the first report of the isolation of $\mathbf{1}$ from the natural source. In addition, with TLC analysis, $\mathbf{1}$ was detected from the acetone extract. Thus, the methyl ester of $\mathbf{1}$ was not formed as an artifact from free acids during the extraction and isolation procedures.

The fungal pathogen C. camelliae has been known to cause camellia flower blight disease. Initially, droplets $(20 \mu \mathrm{L})$ of a solution $(\mathrm{mg} / \mathrm{mL})$ of 1 were applied to the surface of the camellia petals. However, the symptoms of disease progression and the lesions seen in camellia flower blight were not observed for $24 \mathrm{~h}$. Thus, in order to evaluate the potential phytotoxicity, 1 was tested on lettuce seeds. The effects of aqueous solutions of 1 , with concentrations ranging between $50 \mu \mathrm{g} / \mathrm{mL}$ and $500 \mu \mathrm{g} / \mathrm{mL}$, on seed germination, root growth, and shoot length of the lettuce were evaluated. Compound $\mathbf{1}$ inhibited the root growth to $40 \%$ of the control at a concentration of $300 \mu \mathrm{g} / \mathrm{mL}$. At the highest concentration $(500 \mu \mathrm{g} / \mathrm{mL}), 1$ displayed an inhibitory effect on seed germination. 


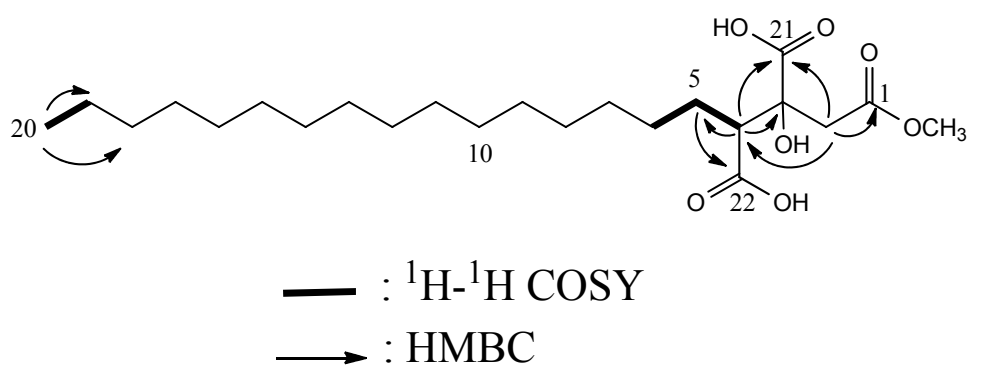

Figure 2. Key HMBC (arrows) correlation of $\mathbf{1}$.

Table 1. NMR Spectroscopic Data (400 MHz, CD 3 OD) for 1.

\begin{tabular}{cccc}
\hline \multicolumn{3}{c}{ Compound 1 } \\
\hline No. & $\boldsymbol{\delta}_{\mathbf{C}}$, type & $\boldsymbol{\delta}_{\mathbf{H}}(\boldsymbol{J}$ in Hz) & HMBC \\
\hline 1 & $172.3 \mathrm{C}$ & & \\
2 & $23.7 \mathrm{CH}_{2}$ & $2.72, \mathrm{~d}(15.9)$ & $1,4,21$ \\
& & $3.10, \mathrm{~d}(15.9)$ & $1,4,21$ \\
3 & $76.9 \mathrm{C}$ & & \\
4 & $54.8 \mathrm{CH}$ & $2.65, \mathrm{dd},(9.0,2.5)$ & $3,5,21$ \\
5 & $28.2 \mathrm{CH}_{2}$ & $1.73, \mathrm{~m}$ & \\
& & $2.21, \mathrm{~m}$ & \\
$6-19$ & $*$ & $1.26-1.28,(\mathrm{~m})$ & 18,19 \\
20 & $14.5 \mathrm{CH}_{3}$ & $0.89, \mathrm{t}(7.4)$ & \\
21 & $176.4{ }^{\mathrm{a}} \mathrm{C}$ & & 1 \\
22 & $176.2{ }^{\mathrm{a}} \mathrm{C}$ & & \\
$\mathrm{OMe}$ & $52.1 \mathrm{CH}_{3}$ & $3.64,(\mathrm{~s})$ & \\
\hline
\end{tabular}

*28.8 t, 30.5 t, 30.7 t, 30.8 t, 33.1 t, 42.5 t, 48.4 t; ${ }^{\text {a }}$ interchangeable.

\section{Experimental}

\section{General}

Optical rotation value was measured with Horiba SEPA-300 polarimeter (Kyoto, Japan), and IR spectrum was recorded with Jasco J-20A spectrophotometer (Tokyo, Japan). Mass spectra were obtained with Jeol JMS-700 (FABMS) and Synapt G2 (HRESITOFMS) mass spectrometers (Tokyo, Japan). NMR data were recorded on a Jeol EX-400 spectrometer at $400 \mathrm{MHz}$ for ${ }^{1} \mathrm{H}$ and $100 \mathrm{MHz}$ for ${ }^{13} \mathrm{C}$ (Tokyo, Japan). Chemical shifts are given on a $\delta(\mathrm{ppm})$ scale with TMS as an internal standard. ${ }^{1} \mathrm{H}$, ${ }^{13} \mathrm{C}$, DEPT, COSY, ${ }^{13} \mathrm{C}-{ }^{1} \mathrm{H}$ COSY and HMBC spectra were recorded using standard Jeol standard pulse sequences. Chemical shifts are given on a $\delta(\mathrm{ppm})$ scale with $\mathrm{CD}_{3} \mathrm{OD}$ as an internal standard. Column chromatography was conducted on silica gel 60 (Merck, MercK KGaA, Darmstadt, Germany) and ODS (Chromatolex ODS, Fuji Silysia). TLC was carried out using precoated silica gel plates (0.5 mm; Merck and Macherey-Nagel and Co., MercK KGaA, Darmstadt, Germany), and spots were detected by spraying with $10 \%$ vanillin in $\mathrm{H}_{2} \mathrm{SO}_{4}$ followed by heating, or by UV irradiation. 


\section{Biological Material}

The fruiting bodies of Ciborinia camelliae Kohn were collected at Tsuruoka city, Yamagata Prefecture, Japan, in Autumn 2008 and identified by one of authors (Y.S.). A voucher specimen has been deposited in the Faculty of Agriculture, Yamagata University, Yamagata, Japan.

\section{Extraction and Isolation}

Dried fruiting bodies (450 g) of Ciborinia camelliae Kohn were extracted with acetone. The acetone extract was evaporated in vavuo and the acetone extract was concentrated to give a residue (10.5 g). The resulting residue concentrate was partitioned into $n$-hexane and EtOAc layers. The purification of the EtOAc layer was guided by the intense brown characteristic coloration with vanillin-sulfuric acid solution on TLC plates. The EtOAc layer $(8.8 \mathrm{~g})$ was chromatographed on a silica gel column using stepwise elution with $n$-hexane-EtOAc (100:0-0:100) followed by stepwise elution with EtOAc$\mathrm{MeOH}$ (100:0-0:100) to give fractions 1-13 (Fr. 1-1-1-13). Fractions 1-6 (1.05 g, $n$-hexane-EtOAc, 50:50) was chromatographed on silica gel using a stepwise gradient of $\mathrm{CHCl}_{3}-$ EtOAc $(100: 0-0: 100)$ to afford fractions 2-1 2-11. Fraction 2-3 $\left(\mathrm{CHCl}_{3}-\mathrm{EtOAc}, 80: 20\right)$ was rechromatographed by ODS column chromatography by eluting with $\mathrm{H}_{2} \mathrm{O}$ and an increasing ratio of $\mathrm{MeOH}$ to afford fractions 3-1 3-11. Compound 1 (28.0 mg) was isolated from Fr. 3-7 ( $\left.\mathrm{H}_{2} \mathrm{O}-\mathrm{MeOH}, 40: 60\right)$ as an amorphous powder;

IR $\left(\mathrm{KBr}, \mathrm{cm}^{-1}\right): 3463(\mathrm{OH}), 1737(\mathrm{C}=\mathrm{O}), 1698(\mathrm{C}=\mathrm{O})$.

${ }^{1} \mathrm{H}\left(400 \mathrm{MHz}, \mathrm{CD}_{3} \mathrm{OD}\right)$ and ${ }^{13} \mathrm{C}\left(100 \mathrm{MHz}, \mathrm{CD}_{3} \mathrm{OD}\right)$ NMR data see Table 1.

$[\alpha]_{\mathrm{D}}^{20}+84^{\circ}\left(\mathrm{c} 0.04, \mathrm{CH}_{3} \mathrm{OH}\right)$

FABMS: $m / z 417(\mathrm{M}+\mathrm{H})^{+}$.

HRESITOFMS: $m / z 431.2910$ (calcd for $\mathrm{C}_{23} \mathrm{H}_{43} \mathrm{O}_{7}, 431.3009$ ).

\section{Methyl Ester Derivative of Compound $\mathbf{1}$}

Compound $1(10 \mathrm{mg})$ was dissolved in a solution of $\mathrm{MeOH}$, and trimethylsilyldiazomethane $(2.0 \mathrm{M}$ in diethylether, $0.05 \mathrm{~mL}$ ), was added to the solution. The mixture was stirred at $0{ }^{\circ} \mathrm{C}$ for 5 min and evaporated to dryness. The residue $(9.2 \mathrm{mg})$ was subjected to silica gel column chromatography with mixtures of $n$-hexane-EtOAc to afford a trimethyl ester $(6.0 \mathrm{mg})$.

${ }^{1} \mathrm{H}-\mathrm{NMR}$ (400 MHz; CD $\left.3 \mathrm{OD}\right): \delta_{\mathrm{H}} 0.88(3 \mathrm{H}, \mathrm{t}, J=7.4 \mathrm{~Hz}, \mathrm{Me}-20), 1.80$ (1H, m, H-5), 1.24-1.26 (28H, m), 1.47 (1H, m, H-5), 2.68 (1H, m, H-4), $2.72(1 \mathrm{H}, \mathrm{d}, J=16.0 \mathrm{~Hz}, \mathrm{H}-2), 3.10$ (1H, d, $J=16.0 \mathrm{~Hz}, \mathrm{H}-2)$, $3.67,3.71,3.82\left(\right.$ each $\left.3 \mathrm{H}, \mathrm{OCH}_{3}\right)$.

${ }^{13} \mathrm{C}-\mathrm{NMR}\left(100 \mathrm{MHz} ; \mathrm{CD}_{3} \mathrm{OD}\right): \delta \mathrm{H} 14.1\left(\mathrm{CH}_{3}, \mathrm{C}-20\right), 22.7\left(\mathrm{CH}_{2}, \mathrm{C}-2\right), 27.1,27.7,29.4,29.5,29.6$, 29.7, 31.9, 40.8 (each $\mathrm{CH}_{2}$, C-5-C19), 51.9, 52.0, 53.2 (each $\left.\mathrm{CH}_{3}, \mathrm{OCH}_{3}\right), 53.8$ (CH, C-4), 75.9 (C, C-3), 174.1 172.9, 171.7, (each C, C-1, C-21, C-22). 
HRESITOFMS: $m / z$ 459.3382 (calcd for $\mathrm{C}_{25} \mathrm{H}_{47} \mathrm{O} 7,459.3322$ ).

\section{Supplementary Materials}

${ }^{1} \mathrm{H},{ }^{13} \mathrm{C}$ NMR, ${ }^{13} \mathrm{C}-{ }^{1} \mathrm{H}$ COSY, and HMBC spectra for compound $\mathbf{1}$ and ${ }^{1} \mathrm{H}$ and ${ }^{13} \mathrm{C}$ NMR spectra for methyl ester derivative are available in the supporting information.

\section{Acknowledgments}

Financial assistance from 'JSPS KAKENHI Grant Numbers (19780083)' has gratefully been acknowledged.

\section{Author Contributions}

Yoshihito Shiono researched data and wrote the manuscript. Yoshihito Shiono, Tetsuya Murayama and Takuya Koseki analyzed the data and performed data acquisition. All authors read and approve the final manuscript.

\section{Conflicts of Interest}

The authors declare no conflict of interest.

\section{References and Notes}

1. Denton-Giles, M.; Bradshaw, R.E.; Dijkwel, P.P. Ciborinia camelliae (Sclerotiniaceae) Induces Variable Plant Resistance Responses in Selected Species of Camellia. Phytopathology 2013, 103, 725-732.

2. Otta, Y.; Amano, K.; Nishiyama, K.; Ando, A.; Ogawa, S.; Nagata, Y. Purification and Properties of a Lectin from Ascomycete Mushroom, Ciborinia camelliae. Phytochemistry 2002, 60, 103-107.

3. Taylor, C.H.; Long, P.G. Review of Literature on Camellia Flower Blight Caused by Ciborinia camelliae. N. Z. J. Crop Hortic. Sci. 2000, 28, 123-138.

4. Thoms, H.; Vogelsang, J. To the Knowledge of Agricin Acid. Justus. Liebigs Ann. Chem. 1907, $357,145-170$.

5. García, N.; Zazueta, C.; Pavón, N.; Chávez, E. Agaric Acid Induces Mitochondrial Permeability Transition Through Its Interaction with the Adenine Nucleotide Translocase. Its Dependence on Membrane Fluidity. Mitochondrion 2005, 5, 272-281.

(C) 2015 by the authors; licensee MDPI, Basel, Switzerland. This article is an open access article distributed under the terms and conditions of the Creative Commons Attribution license (http://creativecommons.org/licenses/by/4.0/). 